\title{
Preventing Sexual Violence against Women and Children: a Comprehensive Research Perspective
}

\section{Gunda Wössner}

Department of Criminology at the Max Planck Institute for the Study of Crime, Security and Law (prior to March 2020: Max Planck Institute for Foreign and International Criminal Law)

\begin{abstract}
Sexual violence against women is one of the most urgent challenges of gender research worldwide. The Department of Criminology at the Max Planck Institute for the Study of Crime, Security and Law (formerly: Max Planck Institute for Foreign and International Criminal Law) has carried out a number of different research projects to explore victimisation and sexual delinquency, and how to deal with sex offenders. This article provides an overview of these research projects. In doing so, a particular focus is placed on a project that is currently nearing completion. This project evaluates the treatment of convicted sex offenders, identifies risk factors for reoffending, and analyses the lives of sex offenders after prison release.
\end{abstract}

\section{INTRODUCTION}

In the 1990s, several sex offences against women and children, especially those committed by previously convicted sex offenders, hit the headlines and thus raised the public and political awareness of sex offenders in many countries. This led to a number of reforms in the area of sex offences. ${ }^{1}$ One of these reforms was implemented in January 1998 with the "Gesetz zur Bekämpfung von Sexualdelikten und anderen gefährlichen Straftaten" (Law to Combat Sex Offences and Other Dangerous Criminal Acts). In accordance with this act, as of 2003, all sex offenders serving a prison sentence of two years or more were to be mandatorily transferred to so-called social therapeutic correctional treatment facilities-prison wards or inde-

1 For an overview, see Wössner/Quenzer/Vig, 2011, pp. 375-393. 
pendent prison units where prisoners undergo therapeutic treatment. Against this background, the Department of Criminology at the Max Planck Institute for the Study of Crime, Security and Law, together with the Ministry of Justice in the Free State of Saxony, set up a longitudinal study to analyse recidivism of sex offenders and how it is related to correctional treatment. ${ }^{2}$ Another question that was addressed was whether the focus on sex offenders is reasonable, as a large number of recidivist sex offenders do not commit the same type of offence for which they were previously convicted. A major aim of this research endeavor is to contribute to tertiary prevention; that is, improving the rehabilitation of convicted sex offenders and preventing them from relapsing, thus paying due regard to the protection of victims - especially women as victims of sex offencesand to the protection of the general public. In addition, the Freiburg Cohort Study has been investigating group-based trajectory models of crime, thus shedding light on the emergence and evolution of crime, judicial reactions towards crime, and criminal careers. ${ }^{3}$ Moreover, the Max Planck Institute is part of a nationwide longitudinal research project on criminal sanctions and recidivism, ${ }^{4}$ which aims to reveal important findings on patterns of sexual offending and recidivism.

This offender-focused research strand has been complemented by several victimological studies ${ }^{5}$ and a study on the possibilities and limits of restorative justice approaches in cases of sexual violence. ${ }^{6}$ The latter study was developed because the needs and responsibilities of those immediately involved (i.e., victims and perpetrators of sex offenders) are not necessarily being met by the criminal justice system.

This article provides an overview of the research activities being conducted at the Max Planck Institute for the Study of Crime, Security and Law and the state of play in these areas of research.

\section{RESEARCH FOCUS 1: VICTIMS OF SEXUAL VIOLENCE}

Victimology has evolved as a key area of research in criminology, with a particular interest in sexual victimisation that started prior to the "me too"

2 Wössner/Hefendehl/Albrecht, 2013.

3 Grundies, 2013, pp. 36-52.

4 Jehle/Albrecht/Hohmann-Fricke/Tetal, 2016.

5 Kury/Chouaf/Obergfell-Fuchs/Wössner,2004; Kury/Obergfell-Fuchs/Wössner, 2004, pp. 749-769.

6 Zinsstag/Keenan/Wössner/De Brouwer/Bolivar/O'Nolan/Busck-Nielsen, (in press). 
debate. First and foremost, it is crucial to try to understand the true extent of sexual victimisation, since a large number of sexual assaults remain in what is known as the dark (hidden) figure of crime. Why this is the case is another important area of research. Approximately one in two women in Western societies experiences some kind of sexual victimisation at least once in her lifetime. ${ }^{7}$ In most sex crime cases, the offender and the victim know each other, ${ }^{8}$ and especially "severe sexual offences are committed by offenders who are close to the victim (i.e., friends, family)". ${ }^{9}$ The closer the victim-offender relationship is, the lower a victim's willingness to report the crime. It is important to note that, even in victim surveys, it is a major challenge to gather the real number of sexual victimisations. Different victimisation surveys may result in different victimisation rates, because the response behaviour largely depends on how the questions are phrased, and whether, and how, a statutory crime is described in everyday language. ${ }^{10}$

Victims and survivors of sexual assaults have multiple needs. Very often, preliminary and criminal proceedings do not meet these needs. This may not only contribute to the aforementioned reluctance to report sexual assaults but also have detrimental effects on the survivor's psychological and physical well-being. Victims, in particular, want and need to receive answers about what happened to them. They also need the offender to acknowledge the harm done and to take responsibility for this. Thus, it comes as no surprise that those involved, especially victims, are the ones seeking alternative approaches to the injustice they have suffered. While restorative approaches are increasingly being applied to minor offences, practitioners and the judicial world in general are particularly cautious in applying restorative justice (RJ) to sex offences. As a result, victims of sex offences are very often the main instigators of an RJ process. Therefore, $\mathrm{RJ}$ practice in cases of sexual violence is ahead of theory concerning this alternative approach. Even though RJ may be very beneficial in cases of sexual violence, it is associated with a number of challenges and limitations that were identified in an international project on exploring the potential of RJ in cases of sexual violence. ${ }^{11}$ For instance, $\mathrm{RJ}$ is a flexible and responsive approach to meeting not only the needs of victims but also those of the offenders and the communities involved. Among the most striking benefits are an improved perception of justice, improved psychological well-being

7 Kury/Chouaf/Obergfell-Fuchs/Wössner, 2004, pp. 589-602.

8 Kury/Obergfell-Fuchs/Wössner, 2004, pp. 749-769.

9 Kury/Obergfell-Fuchs/Wössner, 2004, pp. 749-769.

10 Kury/Obergfell-Fuchs/Kloppenburg/Wössner, 2003, pp. 277-320.

11 Zinsstag/Keenan/Wössner/DeBrouwer/Bolivar/O'Nolan/Busck-Nielsen, (in press). 
(e.g., by being more actively involved in the criminal justice procedure compared to the victim's traditional passive role in formal court proceedings), and the opportunity to resolve relationship issues with the offender. There are, however, still a number of unsolved questions and challenges concerning issues such as the relationship between RJ and therapy, ${ }^{12} \mathrm{RJ}$ and the criminal justice system, and the role and definition of communities in RJ. The latter is a result of the important role communities have been playing in the development of RJ practice around the world. ${ }^{13}$ In addition, the positive outcomes of $\mathrm{RJ}$ in cases of sexual violence must be interpreted cautiously, since these positive outcomes are based on a limited body of research. In any case, preparation, adequate procedural safeguards, and trained and experienced facilitators are essential components of successful RJ programs.

\section{RESEARCH FOCUS 2: THE EFFECTIVENESS OF OFFENDER TREATMENT TO REDUCE RECIDIVISM}

A key question in criminological research is what causes serious crimes such as sex offences and whether, and under which conditions, criminal recidivism can be reduced. In this regard, the correctional treatment of offenders, in particular sex offenders, is of major interest, as these offences may result in long-term consequences for victims and survivors in various aspects. These aspects include mental and physical health, as well as negative economic, financial, and social consequences. ${ }^{14}$ Therefore, it is of great societal interest to constantly refine our understanding of how to prevent such crimes, not only in terms of primary but also in terms of secondary and tertiary prevention. A number of comprehensive reviews have identified core risk factors for offending and reoffending. It is assumed that the treatment of the core risk factors that are amenable to change results in a therapeutic change and hence reduces recidivism-a rationale that is central to the development of sex offender treatment approaches. ${ }^{15}$

According to the current state-of-the-art for sex offender treatment, cognitive-behavioural treatment reduces recidivism. However, the effects are very small. For this reason, the Max Planck Institute for the Study of

12 Wösner, 2017, pp. 248-264.

13 Zinsstag/Keenan/Wössner/DeBrouwer/Bolivar/O'Nolan/Busck-Nielsen (in press).

14 Jewkes/Sen/Garcia-Moreno, 2002, pp. 147-182.

15 Wössner/Schwedler, 2014. 
Crime, Security and Law-following the Institute's long tradition of conducting prison research-analysed whether, and under which conditions, correctional treatment of sex offenders reduces recidivism, with the aim of contributing to the further development of sex offender treatment. To this end, a longitudinal prospective study was carried out. A total sample of over 400 sex and violent offenders was explored at several points of data collection-first, at the beginning of the offenders' incarceration; second, shortly before the offender's prison release; and third, on average 18 months after release. A variety of information was collected over the data points, including each subject's personal history, personality, and criminogenic risk factors; the kind of correctional treatment the subjects underwent; and their social situation in the community, including information on self-reported delinquency at the third data collection point in the study. In addition, official criminal records were analysed at a fourth data collection point. The study took a multimethodological approach, including different quantitative and qualitative methods. The main objective of this research project was to analyse recidivism amongst sex offenders and how it is related to correctional treatment. A secondary goal was to further develop the theoretical understanding of sexual delinquency. In this context, Gottfredson and Hirschi's "General Theory of Crime" was of particular interest, as a large number of recidivist sex offenders do not commit the same type of offence for which they were previously convicted. As such, certain non-offence-specific etiological factors might be of relevance. ${ }^{16}$ This is closely linked to the third goal, improving the risk assessment for sex offenders. Finally, the lives of sex offenders after prison release were examined, because surprisingly little is known about the actual life of sex offenders post-incarceration. In order to better understand the offender-specific characteristics of these research questions, the study examined not only sex offenders but also violent offenders. The results of this study provide answers to some of the most urgent questions with regard to managing sex offenders. It could be shown, for instance, that correctional treatment yields prosocial changes in sex offenders and violent offenders. However, this therapeutic outcome does not easily translate into a lowered risk of criminal involvement post-release and challenges major assumptions of offender treatment. ${ }^{17}$ The study's findings on the lives of sex offenders and violent offenders after prison release contribute to the discussion of why this treatment effect fails to appear. Sex offenders, in particular, are con-

16 Siegfried/Wössner, 2016.

17 Wössner/Schwedler, 2014. 
fronted with several obstacles, difficulties, and stigma after prison release. Whether they successfully cope with these impediments depends on a multifaceted dynamic between their social situation (e.g., having a supportive relationship), functional or dysfunctional coping strategies, adherence to probation conditions, and very often on mental health issues, such as substance abuse problems. Likewise, narratives of change and narratives of being disadvantaged manifest their effects within this complex dynamic. ${ }^{18}$ Bearing these results in mind, it should be emphasised that severe crimes (e.g., sex crimes) are rare and that the majority of these crimes are committed by a small group of multiple offenders. ${ }^{19}$ Thus, a relapse with a new sex offence is a rare event among the majority of persons who already committed a sex offence. The most promising prevention strategy is to focus on identifying high-risk children and juveniles and to provide them with early intervention measures in order to prevent them from sexually offending in the first place. In most cases, incarceration, especially long-term incarceration, is not associated with a lower risk of reoffending, since they hinder efforts to rehabilitate offenders. Lastly, it should be emphasised that most sex offenders do not recidivate with a new sex offence. ${ }^{20}$

\section{CONCLUSION AND OUTLOOK}

Sexual violence against women has remained a politically and emotionally charged topic over the last several decades. Even though the body of scientific knowledge about sex offending and sexual victimisation has been growing steadily, there are still a lot of unanswered questions. One of the aims of the researchers at the Max Planck Institute for the Study of Crime, Security and Law has been to help find answers to these questions. In doing so, both the victim's and the offender's perspectives are considered. The research conducted at the Department of Criminology aligns well with the Department of Criminal Law's new research project "Sexual Autonomy and Sexual Offences." The purpose of this project is to trace and evaluate developments in sexual offences law, to identify best models and practices for future law reforms, and to provide a better understanding of the concept of sexual autonomy.

18 Wössner/Gauder/Czudnochowski, 2019, pp. 66-78; Wössner/Wienhausen-Knezevicl Gauder, 2016.

19 Albrecht/Grundies, 2007, pp. 447-475.

20 Albrecht/Grundies, 2007; Jehle/Albrecht/Hohmann-Fricke/Tetal, 2016. 
Sexual violence against women, but also against men and children, has a social dimension that needs to be recognised and understood. It is a weapon of warfare and a hallmark of female oppression. Science can help to better understand, and hence to change, the roots of sexual violence against women.

\section{REFERENCES}

Albrecht, Hans-Jörg, and Volker Grundies. (2007). Sexuelle Gewaltkriminalität im Lebenslängsschnitt. Die Entwicklung von Sexualkriminalität an Hand von Daten der Freiburger Kohortenstudie. In Friedrich Lösel, Doris Bender, \& JörgMartin Jehle (Eds.), Kriminologie und wissensbasierte Kriminalpolitik: Entwicklungs- und Evaluationsforschung (pp. 447-475) Neue Kriminologische Schriftenreihe. Forum Verlag Godesberg.

Grundies, Volker. (2013). Gibt es typische kriminelle Karrieren? In Dieter Dölling \& Jörg-Martin Jehle (Eds.), Täter $\bullet$ Taten $\bullet$ Opfer. Grundlagenfragen und aktuelle Probleme der Kriminalität und ibrer Kontrolle (pp. 36-52). Forum Verlag Godesberg.

Jehle, Jörg-Martin, Hans-Jörg Albrecht, Sabine Hohmann-Fricke, and Carina Tetal. (2016). Legalbewährung nach strafrechtlichen Sanktionen: Eine bundesweite Rückfalluntersuchung 2010 bis 2013 und 2004 bis 2013. (Bundesministerium der Justiz und für Verbraucherschutz, Ed.) recht. Forum Verlag Godesberg.

Jewkes, Rachel, Puma Sen, and Claudia Garcia-Moreno. (2002). Sexual violence. In Etienne G. Krug, Linda L. Dahlberg, James A. Mercy, Anthony B. Zwi \& Rafael Lozano (Eds.), World Report on Violence and Health (pp. 147-182). World Health Organization.

Kury, Helmut, Joachim Obergfell-Fuchs, Vanessa Kloppenburg, and Gunda Wössner. (2003). New approaches to preventing sexual crimes in Germany. In Helmut Kury, and Joachim Obergfell-Fuchs (Eds.), Mainzer Schriften zur Situation von Kriminalitätsopfern. Crime Prevention. New Approaches (pp. 277-320). Weisser Ring Verlags-GmbH.

Kury, Helmut, Joachim Obergfell-Fuchs, and Gunda Wössner. (2004). The extent of family violence in Europe. A comparison of national surveys. Violence against Women, 10(7), 749-769.

Kury, Helmut, Silvia Chouaf, Joachim Obergfell-Fuchs, and Gunda Wössner. (2004). The Scope of Sexual Victimization in Germany. Journal of Interpersonal Violence, 19(5), 589-602.

Siegfried, Cornelia, and Gunda Wössner. (2016). The explanatory power of the General Theory of Crime: A comparative analysis of a general population and serious offender sample. Deviant Behavior, 37(5), 509-524. 
Wössner, Gunda. (2017). On the relationship between restorative justice and therapy in cases of sexual violence. In Estelle Zinsstag \& Marie Keenan (Eds.), Restorative Responses to Sexual Violence - Legal, Social and Therapeutic Dimensions (pp. 248-264). Routledge.

Wössner, Gunda, Kira-Sophie Gauder, and David Czudnochowski. (2019). Lifecourses of sex and violent offenders after prison release: The interaction between individual- and community-related factors. In: Keesha M. Middlemas \& Carl John Smiley (Eds.), Prisoner Reentry in the 21st Century: Critical Perspectives of Returning Home (pp. 66-78). Routledge.

Wössner, Gunda, Roland Hefendehl, and Hans-Jörg Albrecht. (2013). Sexuelle Gewalt und Sozialtherapie: Bisherige Daten und Analysen zur Längsschnittstudie "Sexualstraftäter in den sozialtherapeutischen Abteilungen des Freistaates Sachsen“. Duncker \& Humblot.

Wössner, Gunda, Carolin Quenzer, and David Vig. (2011). The development of criminal law in Germany with an emphasis on sexual and juvenile offenses. In Helmut Kury \& Evelyn Shea (Eds.), Punitivity - International Developments (pp. 375-393). Brockmeyer Universitätsverlag.

Wössner, Gunda, and Andreas Schwedler. (2014). Correctional treatment of sexual and violent offenders: Therapeutic change, prison climate, and recidivism. Criminal Justice and Behavior, 41(7), 862-879.

Wössner, Gunda, Elke Wienhausen-Knezevic, and Kira-Sophie Gauder. (2016). "I Was Thrown in at the Deep End..." Prisoner Reentry: Patterns of Transition from Prison to Community among Sexual and Violent Offenders (research in brief forschung aktuell No. 48, 2nd ed.). Max-Planck-Institut für ausländisches und internationales Strafrecht.

Zinsstag, Estelle, Marie Keenan, Gunda Wössner, Anne-Marie De Brouwer, Daniela Bolivar, Caroline O'Nolan, and Virginie Busck-Nielsen. (in press). Exploring the Potential of Restorative Justice for Sexual Violence. Oxford University Press.

\section{ABOUT THE AUTHOR}

\section{Gunda Wössner}

Gunda Wössner Ph.D. is a psychologist and senior researcher at the Max Planck Institute for the Study of Crime, Security and Law - Department of Criminology, Freiburg, Germany where she heads up several research projects, including "Sexual offenders in the social therapeutic institutions of the Free State of Saxony". Her research activities focus on correctional treatment, recidivism, rehabilitation and reentry processes of sex offenders and violent offenders, electronic monitoring, and alternative measures such as restorative justice in cases of sexual violence. She has published her research results in various national and international journals and vol- 
umes. From 2015 until 2016, she held a professorship of psychology at the University of Applied Police Sciences Baden-Wuerttemberg, Germany. Her professional activities include teaching various topics of criminology and forensic psychology such as victimology, trauma, crime prevention, psychological aspects of retaliation, hate crimes, radicalisation and conducting workshops on research methods.

\section{Selected Publications:}

Wössner, Gunda. (2017). On the relationship between restorative justice and therapy in cases of sexual violence. In: Estelle Zinsstag, and Marie Keenan (Eds.), Restorative Responses to Sexual Violence: Legal, Social and Therapeutic Dimensions (pp. 248-264). London: Routledge.

Wössner, Gunda. (2016). Women and children as victims of sex offenses: Crime prevention by treating the offenders? In: Helmnut Kury, Sławomir Redo, and Evelyn Shea (Eds.), Women and Children as Victims and Offenders: Background, Prevention, Reintegration (Vol. 2, pp. 525-556). Berlin: Springer.

Wössner, Gunda, and Andreas Schwedler. (2014). Correctional treatment of sexual and violent offenders: therapeutic change, prison climate, and recidivism. Criminal Justice and Behavior, 41(7), 862-879.

\section{ABOUT THE INSTITUTE}

Max Planck Institute for the Study of Crime, Security and Law - Department of Criminology

The research conducted in our three departments-Criminology, Public Law, and Criminal Law-is comparative, international, and interdisciplinary. The overarching goal of research conducted at the Institute is to provide national and supranational criminal policy solutions for the fundamental challenges of our time. The main focus of the Criminology Department is to study why people commit crimes. The goal of the projects conducted in the Criminology Department is to improve the understanding of criminal conduct in order to contribute to the development of prevention strategies. 
